\title{
ANALISIS FAKTOR-FAKTOR YANG MEMENGARUHI TINGKAT PEROLEHAN MARGIN DENGAN AKAD MURABAHAH PADA BANK SYARIAH $X$
}

\author{
${ }^{1}$ Muhammad Yusuf; ${ }^{2}$ Rini Kurnia Sari \\ ${ }^{1}$ Accounting and Finance Department, Faculty of Economic and Communication, BINUS University \\ ${ }^{2}$ Management Department, School of Business Management, BINUS University \\ Jln. K. H. Syahdan No. 9, Palmerah, Jakarta Barat 11480 \\ yusuf_moch2002@yahoo.com; rini_kurnia_sari@yahoo.com
}

\begin{abstract}
This study aims to find out and analyze the factors that affect the level of turnover margin financing murabahah contract on Sharia Bank $X$ and to know the most influential factor on the level of revenue and margins with murabaha contract to know the calculation of turnover margin murabaha financing. The population of this research was the financial statement and the sample was quarterly income statement from 2005 until 2011. This study employed a secondary data collection methods and field research by doing research on Muamalat Institute. Analysis tools used SPSS software version 19.0. Based on the results, the study indicated that factors affecting the level of margin financing murabaha are the overhead cost factor with $R 2$ of 0.73 and test results of F-test of 72.684, as well as a significant level of 0.0001 and administrative costs with the R2 of 0.93 and test results F-test of 72.684, as well as a significant level of 0.037 . While, the financing volume factor does not affect the rate of margin on murabaha financing. The most influential factor is the overhead factor.
\end{abstract}

Keywords: overhead costs, administrative costs, murabahah, margin funding, funding volume

\begin{abstract}
ABSTRAK
Penelitian ini bertujuan untuk mengetahui dan menganalisis faktor-faktor yang memengaruhi tingkat perolehan margin pembiayaan dengan akad murabahah pada Bank Syariah $X$ dan untuk mengetahui faktor yang paling berpengaruh terhadap tingkat perolehan margin dengan akad murabahah serta perhitungan perolehan margin pembiayaan murabahah. Populasi penelitian ini adalah laporan keuangan dan yang menjadi sampel adalah laporan laba rugi triwulan dari tahun 2005 sampai dengan 2011. Penelitian menggunakan pendekatan kuantitatif dengan metode pengumpulan data sekunder dan penelitian lapangan dengan melakukan riset pada Muamalat Institute. Alat analisis menggunakan software SPSS versi 19.0. Hasil penelitian menunjukkan bahwa faktor yang memengaruhi tingkat margin pembiayaan murabahah adalah faktor biaya overhead dengan $R^{2}$ sebesar 0,73 dan hasil uji F-test sebesar 72,684, serta tingkat signifikan 0,0001 dan biaya administrasi dengan dengan $R^{2}$ sebesar 0,93 dan hasil uji F-test sebesar 72,684, serta tingkat signifikan 0,037. Sedangkan faktor volume pembiayaan tidak berpengaruh terhadap tingkat perolehan margin pada pembiayaan murabahah. Faktor yang paling berpengaruh adalah faktor biaya overhead.
\end{abstract}

Kata kunci: biaya overhead, biaya administrasi, murabahah, margin, pembiayaan, volume pembiayaan 


\section{PENDAHULUAN}

Pada awal berdirinya bank syariah, banyak pengamat perbankan yang meragukan akan eksistensi bank syariah. Di tengah-tengah bank konvensional yang sedang menanjak dan menjadi pilar ekonomi Indonesia, bank syariah mencoba memberikan jawaban atas keraguan yang banyak timbul. Munculnya konsep perbankan syariah berdasarkan prinsip bagi hasil dinilai lebih menguntungkan daripada bank konvensional yang masih menerapkan sistem bunga. Hal ini disebabkan karena sistem bagi hasil pada bank syariah tidak terpengaruh oleh negative spread. Bank syariah tidak dibebankan membayar bagi hasil yang jumlahnya tetap, namun besarnya bagi hasil yang diberikan sesuai dengan besarnya pendapatan usaha yang diperoleh bank syariah sehingga besarnya bagi hasil setiap bulannya tidak selalu sama. Sedangkan bank konvensional dibebankan membayar bunga yang jumlahnya tetap tanpa memperhitungkan besar kecilnya pendapatan usaha bank. Sehingga ketika terjadi krisis, bank konvensional mengalami kesulitan karena bunga yang harus dibayar jumlahnya tetap sementara pembayaran kredit oleh nasabah tersendat. Oleh karena itu perbankan syariah diharapkan dapat menjadi solusi untuk menciptakan sektor riil dan memberikan efek makro untuk menciptakan kesejahteraan ekonomi.

Bank syariah hadir sebagai representasi kebutuhan masyarakat muslim di sektor keuangan yang mengacu pada konsep maslahat. Dalam perkembangannya, pertumbuhan yang mengesankan terjadi pada bank syariah. Bank syariah di Indonesia menghimpun dana melalui prinsip wadiah dan mudharabah. Dana ini kemudian dipergunakan untuk penyaluran dana dalam bentuk pembiayaan dengan prinsip bagi hasil, jual beli, dan sewa.

Seperti yang terjadi dengan industri perbankan Indonesia pascakrisis global yang melanda Indonesia pada kuartal terakhir 2008 menyebabkan perbankan begitu ketat dalam menyalurkan kreditnya. Meskipun beberapa kali Bank Indonesia memangkas suku bunga BI (BI Rate) dengan tujuan menurunkan tingkat suku bunga perbankan dengan agresif, hal itu ternyata tidak mampu untuk mendorong perbankan untuk menurunkan tingkat suku bunga kreditnya. Sehingga masyarakat khusunya sektor riil yang sangat membutuhkan dana dalam rangka memulihkan kembali usahanya, kandas kembali.

Selain suku bunga acuan Bank Indonesia (BI Rate) ataupun SBIS yang menjadi dasar bagi penetapan suku bunga kredit bagi perbankan konvensional ataupun nisbah bagi hasil dan margin bagi perbankan syariah, inflasi turut memberikan peranan dalam penetapan tersebut. Kemampuan Bank Indonesia dalam mengeluarkan kebijakan yang mampu untuk ditaati oleh para praktisi perbankan makin lama makin surut.

Menurut Yunita (2007), tingkat suku bunga SBI memengaruhi DPK perbankan syariah. Jika terjadi peningkatan pada suku bunga SBI, terjadi displacement pada dana simpanan sehingga mengakibatkan penurunan jumlah DPK perbankan syariah. Inflasi menyebabkan penurunan daya beli mata uang sehingga dibutuhkan uang dalam jumlah banyak untuk mengonsumsi barang yang sama. Dalam kondisi ini, untuk memenuhi konsumsi masyarakat penarikan dana simpanan perbankan syariah sangat mungkin terjadi. Kenaikan kurs mata uang US \$ menyebabkan penurunan DPK perbankan syariah disebabkan oleh penarikan dana yang dilakukan oleh nasabah bank syariah.

Menurut Jihad (2009), bahwa variabel margin murabahah (negatif), pembiayaan konsumtif (negatif), dan akses masyarakat (positif) yang berpengaruh secara signifikan terhadap permintaan pembiayaan murabahah, dengan asumsi variabel lain diabaikan dan konstan. Menurut Yani (2009), dalam jangka panjang, tingkat suku bunga pinjaman dipengaruhi oleh suku bunga SBI dan PDB. Sedangkan dalam jangka pendek dipengaruhi oleh jumlah uang beredar, suku bunga SBI, dan PDB. 
Untuk variabel inflasi, tidak menunjukan signifikansi dalam jangka panjang maupun jangka pendek dikarenakan kesalahan data pada masa krisis.

Menurut Asmita (2004) mengenai faktor-faktor yang memengaruhi penentuan margin murabahah antara Januari 2001 sampai dengan Desember 2003, hasil penelitian membuktikan bahwa ada tiga variabel yang signifikan memengaruhi penentuan margin murabahah yaitu biaya overhead, cost of fund, dan profit target. Hasil penelitian tersebut membuktikan bahwa penentuan margin murabah Bank Syariah mirip dengan penentuan tingkat kredit bank konvesional. Ketiga variabel tersebut merupakan aspek penentu bagi bank konvensional untuk mengambil tingkat bunga yang akan dibebankan pada suatu pinjaman. Biaya overhead meliputi biaya tenaga kerja, biaya administrasi dan umum, biaya penyusutan, biaya pencadangan penghapusan aktiva produktif, dan biaya lainnya yang terkait dengan operasional bank. Profit target mempertimbangkan tingkat inflasi, tingkat suku bunga pasar, premi risiko, spread, cadangan piutang tertagih.

Berdasarkan uraian dan hasil penelitian sebelumnya, penelitian mengambil judul Analisis Faktor-faktor yang Memengaruhi Tingkat Perolehan Margin dengan Akad Murabahah pada Bank Syariah X. Perumusan masalah dalam penelitian ini adalah tentang faktor-faktor yang memengaruhi tingkat pemerolehan margin pembiayaan dengan akad murabahah Bank Syariah X. Tujuan dan manfaat penelitian ini adalah untuk mengetahui faktor-faktor yang memengaruhi tingkat perolehan margin pembiayaan dengan akad murabahah pada Bank Syariah X; untuk mengetahui faktor yang paling berpengaruh terhadap tingkat perolehan margin pembiayaan dengan akad murabahah pada Bank Syariah X; dan untuk mengetahui perhitungan perolehan margin pembiayaan dengan akad murabahah pada Bank Syariah X.

Hipotesis yang digunakan dalam menganalisis faktor-faktor yang memengaruhi tingkat perolehan margin dengan akad murabahah pada Bank Syariah X sebagai berikut:

\footnotetext{
$\mathrm{H}_{1}$ : Apakah ada pengaruh antara biaya overhead terhadap penentuan margin murabahah pada Bank Syariah X.

$\mathrm{H}_{2}$ : Apakah ada pengaruh antara biaya administrasi terhadap penentuan margin murabahah pada Bank Syariah X.

$\mathrm{H}_{3}$ : Apakah ada pengaruh antara volume pembiayaan terhadap penentuan margin murabahah pada Bank Syariah X.
}

Ruang lingkup dan batasan masalah dalam penelitian ini adalah sebagai berikut. Pertama, tingkat margin pembiayan dengan akad murabahah Bank Syariah X pada periode dari tahun 2005 sampai dengan tahun 2011. Kedua, sampel yang digunakan dalam penelitian ini adalah laporan keuangan triwulan Bank Syariah X dari tahun 2005 sampai dengan tahun 2011. Ketiga, faktor-faktor yang diteliti dibatasi pada faktor biaya overhead, biaya administrasi, dan volume pembiayaan.

\section{Tinjauan Pustaka}

Pembiayaan menurut Muhammad (2005:17): "Pendanaan yang diberikan oleh suatu pihak kepada pihak lain untuk mendukung investasi yang telah direncanakan, baik dilakukan sendiri maupun lembaga. Dengan kata lain, pembiayaan adalah pendanaan yang dikeluarkan untuk mendukung investasi yang telah direncanakan.” Menurut Rivai dan Veithzal (2008:4), pembiayaan adalah: "Penyediaan uang atau tagihan yang dapat dipersamakan dengan itu berdasarkan persetujuan dan kesepakatan pinjam meminjam antara lembaga keuangan pihak lain yang mewajibkan pihak peminjam untuk melunasi utangnya setelah jangka waktu tertentu.” Sementara menurut Antonio (2009:160) adalah pemberian fasilitas penyediaan dana untuk memenuhi kebutuhan pihak-pihak yang merupakan defisit unit. Jayaprawira (2007) mendefinisikan pembiayaan adalah pemberian fasilitas penyedia dana untuk memenuhi kebutuhan pihak-pihak yang merupakan defisit unit. Menurut sifat penggunaannya, pembiayaan dapat dibagi menjadi: pembiayaan produktif, pembiayaan yang ditujukan untuk 
memenuhi kebutuhan produksi dalam arti luas, yakni untuk peningkatan usaha, baik usaha produksi, perdagangan maupun investasi; pembiayaan konsumtif, pembiayaan yang digunakan untuk memenuhi kebutuhan konsumsi, yang akan habis digunakan untuk dipakai memenuhi kebutuhan.

Menurut Pradjoto (2007), pembiayaan syariah adalah sumber pendapatan suatu perbankan syariah berasal dari distribusi pembiayaan (debt financing) yang dilakukan oleh perbankan syariah yang terdiri dari, bagi hasil atas kontrak mudharabah dan kontrak musyarakah, keuntungan atas kontrak jual beli (al bai), hasil sewa atas kontrak ijarah dan ijarah wal iqtina; dan Fee dan biaya administrasi atas jasa-jasa syariah lainnya. Tingkat pembiayaan dalam perbankan dapat diukur dengan menggunakan dua rasio utama (disamping beberapa rasio lain yang digunakan sebagai pendukung). Pertama adalah rasio FDR (Finance to Deposit Ratio), yaitu perbandingan antara jumlah pembiayaan terhadap deposit bank. kedua adalah rasio CAR (Cash Adequate Ratio).

Menurut Rivai danVeithzal (2007), Financing Deposit Ratio (FDR) adalah rasio untuk mengukur seberapa jauh kemampuan bank dalam membayar semua dana masyarakat serta modal sendiri dengan mengandalkan kredit yang telah didistribusikan ke masyarakat. Menurut Indah (2006) kenaikan dan penurunan FDR dipengaruhi oleh berbagai faktor, antara lain: tingkat biaya dana (cost of fund), margin yang diinginkan, biaya operasional (overhead cost), dan tingkat risiko kredit. Menurut Rivai danVeithzal (2007:770): “Capitar Adequacy Ratio (CAR) adalah rasio yang digunakan untuk mengukur seberapa jauh aktiva bank yang menggunakan risiko ikut dibiayai dari modal sendiri disamping memperoleh dana-dana dari sumber di luar bank.” Rumus untuk menghitung CAR adalah:

$$
\mathrm{CAR}=\frac{\text { Modal Bank }}{\text { Aktiva Tertimbang Menurut Resiko(ATMR) }} \quad \mathrm{x} 100 \%
$$

Salah satu skim fiqih yang paling populer digunakan oleh perbankan syariah adalah skim jualbeli murabahah. Transaksi murabahah ini lazim dilakukan oleh Rasulallah SAW dan para sahabatnya. Secara sederhana, murabahah berarti suatu penjualan barang seharga barang tersebut ditambah keuntungan yang disepakati. Misalnya, seseorang membeli barang kemudian menjualnya kembali dengan keuntungan tertentu. Besar keuntungan tersebut dapat dinyatakan dalam nominal rupiah tertentu atau dalam bentuk persentase dari harga pembeliannya, misalnya $10 \%$ atau $20 \%$. Menurut Karim (2006:113), murabahah adalah "Akad jual-beli barang dengan menyatakan harga perolehan dan keuntungan (margin) yang disepakati oleh penjual dan pembeli. Karena dalam definisinya disebut adanya keuntungan yang disepakati, karakteristik murabahah adalah si penjual harus memberi tahu pembeli tentang harga pembelian barang dan menyatakan jumlah keuntungan yang ditambah pada biaya tersebut.”

Menurut Pedoman Akuntansi Perbankan Syariah Indonesia (2003:32), murabahah adalah transaksi penjualan barang dengan menyatakan harga perolehan dan keuntungan (margin) yang disepakati oleh penjual dan pembeli. Sedangkan menurut Perwataatmadja dan Antonio (1992), murabahah adalah pembelian yang diberikan kepada nasabah dalam rangka pemenuhan kebutuhan produksi. Murabahah menurut jenisnya dapat dikategorikan dalam Murabahah tanpa pesanan, artinya ada yang beli atau tidak, bank syariah menyediakan barang; dan Murabahah berdasarkan pesanan artinya bank syariah baru akan melakukan transaksi jual beli jika ada pesanan. Murabahah berdasarkan pesanan dapat dikategorikan dalam: sifatnya mengikat, artinya murabahah berdasarkan pesanan tersebut mengikat untuk dibeli oleh nasabah sebagai pemesan; dan sifatnya tidak mengikat, artinya walaupun nasabah telah melakukan pemesanan barang, nasabah tidak terikat untuk membeli barang tersebut. Dari cara pembayaran, murabahah dapat dikategorikan menjadi pembayaran tunai dan pembayaran tangguh. Pada praktik yang dilakukan oleh bank syariah saat ini adalah Murabahah berdasarkan pesanan, sifatnya mengikat dengan cara pembayaran tangguh. 


\section{METODE PENELITIAN}

Penelitian yang dilakukan menggunakan jenis penelitian kuantitatif. Alasannya penulis ingin mengetahui nilai satu variabel atau lebih (independen) dengan tidak membandingkan atau menghubungkan dengan variabel lain yang tidak dilakukan dalam penelitian ini. Pada penelitian ini terdapat tiga variabel yang akan digunakan, yaitu tiga variabel bebas (independent variabel) dan satu variabel terikat (dependent variabel). Dalam penelitian ini variabel dependen yang digunakan adalah margin pembiayaan murabahah. Margin murabahah merupakan pendapatan margin yang ditangguhkan yang dapat diakui karena telah jatuh tempo atau telah dilunasi piutang murabahah. Variabel Independen atau bebas adalah variabel yang dapat memengaruhi perubahan dalam variabel dependen dan mempunyai hubungan yang positif ataupun yang negatif bagi variabel dependen nantinya.

Dalam penelitian ini terdapat 3 variabel independen yaitu: Pertama, biaya overhead, yaitu biaya yang dikeluarkan oleh bank yang tidak langsung terkait dengan upaya untuk memperoleh dana pihak ketiga. Biaya overhead meliputi biaya tenaga kerja, biaya administrasi dan umum, biaya penyusutan, biaya pencadangan penghapusan aktiva produktif, dan biaya lainnya yang terkait dengan operasional bank.

\section{Overhead Cost $=$ Biaya penyisihan penghapusan aktiva + Biaya estimasi kerugian} komitmen dan kontijensi + B. operasional lainnya

Kedua, administrasi pembiayaan, yaitu pengelolaan biaya yang berhubungan dengan pendidikan mulai dari tingkat perencanaan, sampai pada pengukuran biaya yang efisiensi. Biaya administrasi yang dikenakan adalah sebesar 0,5\% p.a yang dihitung dari maksimum pembiayaan dan dinyatakan dalam nominal dengan ketentuan biaya administrasi dikenakan diluar margin/bagi hasil pembiayaan (disamping dikenakan margin/bagi hasil pembiayaan juga dikenakan biaya administrasi). Ketiga, volume pembiayaan murabahah, yaitu volume pembiayaan murabahah adalah jumlah pembiayaan berskema murabahah yang diberikan oleh bank syariah selama periode akuntansi tertentu.

Sampel data dalam penelitian ini adalah dengan sejumlah volume sampling yaitu laporan triwulan pada Bank Syariah X tahun 2005 sampai dengan 2011. Laporan keuangan yang dimaksud terdiri dari laporan laba rugi dan neraca. Lokasi yang dijadikan objek penelitian ini adalah pada Muamalat Institute yang merupakan lembaga research centre Bank Syariah X. Waktu penelitian adalah selama 6 tahun sejak 2005 sampai dengan 2011.

Penelitian menggunakan dua jenis kelompok data, yaitu data primer dan data sekunder. Data primer pada penelitian ini yaitu dengan melakukan observasi langsung pada objek penelitian yaitu di Muamalat Institute dan wawancara langsung pada pihak yang bersangkutan, yaitu Ibu Diyanti selaku karyawan pada Muamalat Institute. Lembaga ini merupakan lembaga resmi yang dibentuk Bank Syariah X Indonesia yang bertujuan untuk melakukan riset mengenai perbankan syariah oleh lembaga atau instansi maupun mahasiswa. Data Sekunder, data yang digunakan dalam penelitian ini adalah jenis data sekunder kuantitatif. Data sekunder kuantitatif yang digunakan dalam penelitian ini diperoleh dari laporan publikasi Bank Syariah X melalui laporan keuangan triwulan laba rugi dan neraca pada website resmi Bank Syariah X.

Dalam penelitian ini metode analisis data yang digunakan untuk melihat jika biaya overhead, biaya administrasi, dan volume pembiayaan murabahah berpengaruh terhadap penentuan margin murabahah pada Bank Syariah X. Metode analisis data yang digunakan adalah metode analisis regresi sederhana dan analisis regresi berganda dengan alat bantu SPSS 19.0. Analisis ini bertujuan untuk melihat pengaruh dari satu variabel independen terhadap variabel dependen dan pengaruh dari 
sejumlah variabel independen terhadap variabel dependen yang masing-masing memiliki skala rasio/interval.

Uji statistik deskriptif adalah statistik yang digunakan untuk menganalisis data dengan cara mendiskripsikan atau menggambarkan data yang telah terkumpul sebagaimana adanya tanpa bermaksud membuat simpulan yang berlaku untuk umum atau generalisasi. Uji statistik deskriptif yang ditampilkan meliputi nilai minimum, nilai maksimum, mean, dan standar deviasi. Pengujian hipotesis dalam penelitian ini akan dilakukan setelah dilakukan pengujian terhadap data terkait. Pengujian hipotesis dilakukan untuk melihat pengaruh kinerja keuangan terhadap tingkat bagi hasil. Metode analisis regresi sederhana adalah teknik statistikal yang dapat digunakan untuk menganalisis hubungan linear antara satu variabel dependen pada satu variabel independen dengan melakukan estimasi persamaan dari suatu garis lurus. Metode ini digunakan untuk melihat pengaruh biaya overhead, biaya administrasi, dan volume pembiayaan murabahah yang memengaruhi tingkat perolehan margin dengan akad murabahah pada Bank Syariah X.

Metode analisis regresi merupakan teknik statistik yang menganalisis hubungan linear antara sebuah variabel dependen dengan beberapa variabel independen dengan melakukan estimasi persamaan dari suatu garis lurus. Metode ini digunakan untuk menguji pengaruh biaya overhead, biaya administrasi, dan volume pembiayaan murabahah sebagai variabel dependen. Model analisis regresi linear berganda yang digunakan seperti berikut:

$$
\mathrm{Y}_{1}=\mathrm{a}+\mathrm{b}_{1} \cdot \mathrm{X}_{1}+\mathrm{b}_{2} \cdot \mathrm{X}_{2}+\mathrm{b}_{3} \cdot \mathrm{X}_{3}+\mathrm{E}
$$

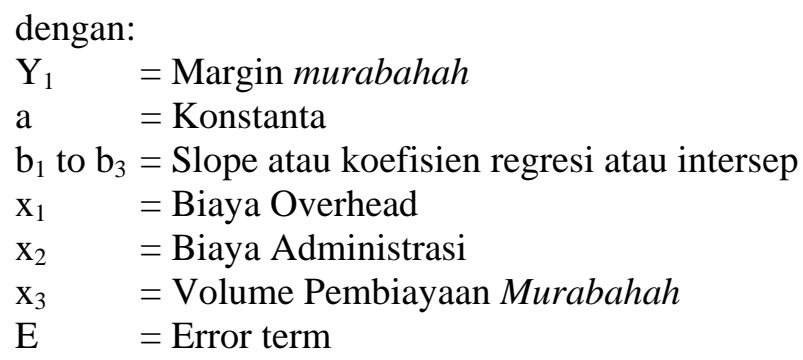

\section{HASIL DAN PEMBAHASAN}

Penelitian ini bertujuan untuk menganalisis faktor-faktor yang memengaruhi margin pembiayaan murabahah periode 2005 sampai dengan 2011. Populasi laporan keuangan triwulan menggunakan 28 laporan keuangan yang menjadi sampel penelitian pada Bank Syariah X. Statistik deskriptif memberikan deskripsi data yang melihat dari standar deviasi, maksimum, minimum, dan rata-rata. Hasil analisis dapat digambarkan pada Tabel 1 sebagai berikut.

Tabel 1 Statistik Deskriptif

\begin{tabular}{lrrrrr}
\hline & N & Minimum & Maximum & Mean & Std. Deviation \\
\hline Margin Pembiayaan Murabahah & 28 & 41494 & 649110 & 266987.25 & 170607.421 \\
Biaya Overhead & 28 & 23314 & 919355 & 270433.14 & 236976.782 \\
Biaya Administrasi & 28 & 36597 & 818223 & 273799.82 & 192152.541 \\
Volume Pembiayaan & 28 & 1044345 & 4374017 & 2900109.46 & 1135303.952 \\
Valid N (listwise) & 28 & & & & \\
\hline
\end{tabular}

(Sumber: Data Diolah, 2012) 
Pada Tabel 1 dapat diketahui bahwa margin pembiayaan murabahah dengan sampel sebanyak 28 memiliki nilai minimum adalah 41494, nilai maksimum adalah 649110. Nilai mean 266987.25 dan standart deviation sebesar 170607.421. Nilai mean berada di atas rata-rata ideal, yaitu 3 yang diperoleh dari perhitungan nilai minimum (41494) ditambah nilai maksimum (649110) dibagi 2 $\{(41494+649110) / 2=345302$. Sedangkan independent variabel dengan sampel sebanyak 28 seperti biaya overhead memiliki nilai minimum adalah 23314 dan nilai maksimum adalah 919355. Nilai mean sebesar 270433.14 dan standart deviation sebesar 236976.782. Biaya administrasi memiliki nilai minimum adalah 36597 dan nilai maksimum adalah 818223. Nilai mean sebesar 273799.82 dan standart deviation sebesar 192152.541. Kemudian volume pembiayaan memiliki nilai minimum 1044345 dan nilai maksimum adalah 4374017. Nilai mean sebesar 2900109.46 dan standart deviasi sebesar 1135303.952.

Berdasarkan hasil analisis pada penelitian, faktor biaya overhead, biaya administrasi, dan volume pembiayaan secara keseluruhan dapat memengaruhi tingkat perolehan margin pada pembiayaan dengan akad murabahah. Namun jika diuji secara terpisah, hanya faktor biaya overhead dan biaya administrasi saja yang dapat memengaruhi tingkat margin pada pembiayaan murabahah. Sedangkan faktor volume pembiayaan tidak berpengaruh terhadap tingkat margin pembiayaan murabahah.

Faktor biaya overhead merupakan faktor yang paling berpengaruh terhadap tingkat margin pembiayaan murabahah. Dengan besarnya $\mathrm{R}^{2} 0,73$, sedangkan dari uji $\mathrm{F}$ test didapat $\mathrm{F}$ hitung sebesar 72,684 dengan tingkat signifikansi 0,001. Makin tinggi biaya overhead yang dikeluarkan bank, tingkat margin akan makin rendah. Namun jika bank dapat menekan biaya overhead, tingkat margin yang diperoleh pun akan makin besar. Sedangkan faktor biaya administrasi juga berpengaruh terhadap tingkat margin pembiayaan murabahah. Makin kecil biaya administrasi yang ditetapkan oleh bank, makin banyak nasabah melakukan pembiayaan pada bank tersebut. Hal ini berarti makin produktif bank dalam beraktivitas yang dapat meningkatkan tingkat margin bank.

Faktor volume pembiayaan tidak berpengaruh terhadap tingkat margin pembiayaan murabahah karena tingkat margin sudah ditetapkan pada awal melakukan akad pembiayaan murabahah. Sedangkan volume pembiayaan merupakan faktor eksternal dalam pembiayaan murabahah. Dengan $\mathrm{R}^{2}$ sebesar 0,53, sedangkan dari uji $\mathrm{F}$ test didapat $\mathrm{F}$ hitung sebesar 29,12 dengan tingkat signifikansi 0,436.

Faktor yang paling berpengaruh terhadap tingkat perolehan margin pembiayaan murabahah adalah faktor biaya overhead. Jika bank dapat menekan biaya overhead, margin yang diperoleh akan semakin besar. Hal ini juga dapat meningkatkan pembiayaan murabahah. Dengan $\mathrm{R}^{2}$ sebesar 0,73, sedangkan dari uji $\mathrm{F}$ test didapat $\mathrm{F}$ hitung sebesar 72,684 dengan tingkat signifikansi 0,001 dan standardized coefficients beta sebesar 0,858, nilai t sebesar 8,525.

Perhitungan untuk menentukan margin murabahah ada beberapa cara, yakni sebagai berikut. Pertama, bank menentukan keuntungan dari jumlah dana yang dipinjam oleh nasabah untuk membeli barang ke bank tersebut sebesar yang disepakati kedua belah pihak.

\section{Rumus Harga Jual (cara pertama)}

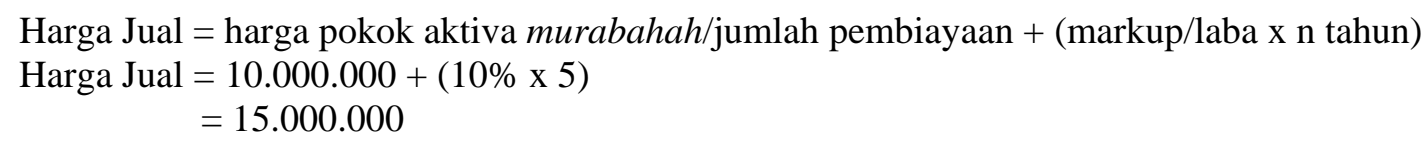

Kedua, atas dasar dana yang dipinjam oleh nasabah, bank syariah menerapkan keuntungan transaksi 20\%. Kemudian jika dibayar satu atau dua tahun, untuk menstabilkan daya beli uang tersebut, bank syariah dapat menambahkan sejumlah dua kali inflasi yang akan datang. Misalnya, 
diperkirakan inflasi 5\% per tahun, maka faktor stabilizer daya beli untuk 2 tahun sama dengan 2 x 5\% $=10 \%$. Jadi selama 2 tahun nasabah mengangsur pokok pinjaman ditambah dengan keuntungan dan inflasi.

\section{Rumus Harga Jual (cara kedua)}

Harga Jual = harga pokok aktiva murabahah/jumlah pembiayaan $+($ inflasi x n) tahun + markup/laba sekali

Harga jual $=10.000 .000+(2 \% x 5)+3.000 .000$

$$
=14.000 .000
$$

Ketiga, dalam penentuan harga jual bank, bank dapat menerapkan metode penetapan harga jual berdasarkan cost plus markup. Dengan metode cost plus, harga jual dapat dihitung dengan rumus sebagai berikut:

\section{Rumus Harga Jual (cara ketiga)}

Harga Jual = harga pokok aktiva murabahah/jumlah pembiayaan + cost recovery + markup/laba sekali Harga Jual $=10.000 .000 / 1+3.000 .000+2.000 .000$

$$
=15.000 .000
$$

Cost recovery adalah bagian dari estimasi biaya operasional bank syariah yang dibebankan pada harga pokok aktiva murabahah/pembiayaan.

\section{Rumus perhitungan cost recovery}

Cost recovery $=$ (harga pokok aktiva murabahah atau pembiayaan/estimasi total pembiayaan) $\mathrm{x}$ estimasi biaya operasi 1 tahun

Markup/laba ditentukan sekian persen dari harga pokok aktiva murabahah/pembiayaan, misalnya $10 \%$. Rumus untuk menghitung margin murabahah adalah sebagai berikut:

Margin murabahah $=($ cost recovery + markup $) /$ harga pokok aktiva murabahah (pembiayaan)

Margin murabahah $=(3.000 .000+2.000 .000) / 10.000 .000=0,5$

\section{SIMPULAN}

Faktor-faktor yang berpengaruh terhadap margin pembiayaan murabahah adalah biaya overhead, biaya administrasi, dan volume pembiayaan yang secara bersama-sama berpengaruh terhadap tingkat margin pembiayaan murabahah pada Bank Syariah X. Dengan kata lain Ho (faktor yang tidak berpengaruh) ditolak atau Ha (faktor yang berpengaruh) diterima. Hal tersebut disebabkan nilai $\mathrm{F}$ hitung sebesar 152,76 dengan tingkat signifikan 0,000 lebih kecil dari 0,005; maka dapat disimpulkan model regresi dapat digunakan untuk memprediksi seluruh faktor untuk menentukan tingkat margin pada pembiayaan murabahah. Hal ini berarti seluruh faktor secara bersamaan dapat memengaruhi tingkat margin pada pembiayaan murabahah. Dengan demikian seluruh faktor secara bersamaan dapat memengaruhi tingkat margin pada pembiayaan murabahah. Sedangkan faktor lain tidak diketahui, karena tidak dilakukan pengujian pada penelitian ini.

Faktor biaya overhead adalah faktor yang paling berpengaruh terhadap tingkat margin pembiayaan murabahah karena biaya overhead memiliki nilai beta yang paling besar dalam model 
analisis regresi. Dengan $\mathrm{R}^{2}$ sebesar 0,73 , sedangkan dari uji F-test didapat $\mathrm{F}$ hitung sebesar 72,684 dengan tingkat signifikansi 0,001 dan standardized coefficients beta sebesar 0,858, nilai t sebesar 8,525. Sedangkan faktor tingkat biaya administrasi juga berpengaruh namun tidak berkorelasi kuat.

Faktor volume pembiayaan adalah faktor yang tidak berpengaruh terhadap margin pembiayaan murabahah karena volume pembiayaan merupakan faktor ekternal dalam pembiayaan sedangkan margin pembiayaan sudah ditetapkan diawal pada saat akad. Dengan hasil uji F-test didapat F hitung sebesar 29,12 dengan tingkat signifikansi 0,436. Karena probabilitas $(0,436)$ jauh lebih besar dari 0,05, model regresi tidak dapat digunakan untuk memprediksi variabel faktor volume pembiayaan margin murabahah.

\section{Saran}

Bank Syariah X diharapkan dapat mengurangi biaya overhead sehingga tingkat margin yang diperoleh akan makin besar sehingga dapat bersaing dengan bank lain dalam meningkatkan volume pembiayaan. Masyarakat diharapkan dapat melakukan pembiayaan pada bank syariah, sehingga dapat tercipta ekonomi Islam yang sesuai dengan ajaran Islam. Bank Syariah $\mathrm{X}$ diharapkan dapat memaksimalkan biaya administrasi yang dibebankan kepada nasabah, sehingga biaya overhead dapat ditekankan. Hal ini juga berdampak pada peningkatan margin pada pembiayaan murabahah. Penelitian selanjutnya dapat menambahkan beberapa faktor lain untuk menganalisis faktor yang dapat memengaruhi tingkat margin pada pembiayaan murabahah. Pada penelitian selanjutnya juga dapat menggunakan objek lain sehingga dapat memberikan simpulan yang lebih pasti.

\section{DAFTAR PUSTAKA}

Antonio, M. S. (2008). Bank Syariah Dari Teori Ke Praktik. Jakarta: Gema Insani.

Asmita, B. (2004). Analisis Faktor yang Mempengaruhi Margin Pembiayaan Murabahah, Studi Kasus pada BPRS PNM Mentari. Jakarta: Universitas Indonesia.

Ghozali, I. (2009). Aplikasi Analisis Multivariate dengan Program SPSS. Semarang: Badan Penerbit Universitas Diponegoro.

Hair, J. F., and Tatham, B. (2006). Multivariate Data Analysis. 5th Ed. London: Prentice Hall International.

Harahap, S. S., Wiroso, dan Yusuf, M. (2010). Akuntansi Perbankan Syariah. Jakarta: LPFE Usakti.

Jayaprawira, A. (2007, 16 Januari). Pola Pembiayaan Usaha Melalui Bank Syariah. Diakses 19 November 2013 dari http://shariahlife.wordpress.com/2007/01/16/pola-pembiayaan-usahamelalui-bank-syariah/

Muhammad. (2005). Pengantar Akuntansi Syariah. Jakarta: Salemba Empat.

Perwataatmadja, K. dan Antonio, M. S. (1992). Apa dan Bagaimana Bank Islam. Yogyakarta: Dana Bhakti Wakaf.

Pradjoto. (2007). Pembiayaan dalam Perbankan Syariah. Jakarta. 
Rivai, V., Veithzal, A. P., and Idroes, F. N. (2007). BANK and Financial Institution Management. Jakarta: Rajagrafindo Persada.

Wiroso. (2009). Produk Perbankan Syariah. Jakarta: LPFE Usakti.

Yaya, R., Martawireja, A. E., dan Abdurahim, A. (2009). Akuntansi Perbankan Syariah. Jakarta: Salemba Empat.

Yunita, P. (2007). Pengaruh Suku Bunga SBI, Tingkat Inflasi dan Kurs US Dollar terhadap Kinerja Penghimpunan Dana Pihak Ketiga Perbankan Syariah. Tesis Magister (dipublikasikan) Fakultas Ekonomi dan Keuangan Syariah, Program Studi Kajian Timur Tengah dan Islam. Jakarta: Universitas Indonesia.

Yusuf, M., dan Wiroso. (2011). Bisnis Syariah. Jakarta: Mitrawacanamedia. 